\title{
Chromium Morpho-Phytotoxicity
}

\author{
Abdul Wakeel and Ming Xu * \\ Key Laboratory of Geospatial Technology for the Middle and Lower Yellow River Regions, \\ College of Environment and Planning, Henan University, Kaifeng 475004, China; abwzju@zju.edu.cn \\ * Correspondence: mingxu@henu.edu.cn
}

Received: 27 March 2020; Accepted: 24 April 2020; Published: 29 April 2020

\begin{abstract}
Chromium ( $\mathrm{Cr}$ ) is considered as one of the chronic pollutants that cause damage to all living forms, including plants. Various industries release an excessive amount of $\mathrm{Cr}$ into the environment. The increasing accumulation of $\mathrm{Cr}$ in agricultural land causes a significant decrease in the yield and quality of economically important crops. The Cr-induced biochemical, molecule, cytotoxic, genotoxic, and hormonal impairments cause the inhibition of plant growth and development. In the current study, we reviewed Cr morpho-phytotoxicity related scientific reports published between 2009 to 2019 . We mainly focused on the Cr-induced inhibition of seed germination and total biomass production. Furthermore, Cr-mediated reduction in the root, branches, and leave growth and development were separately discussed. The $\mathrm{Cr}$ uptake mechanism and interference with the macro and micro-nutrient uptake were also discussed and visualized via a functional model. Moreover, a comprehensive functional model has been presented for the $\mathrm{Cr}$ release from the industries, its accumulation in the agricultural land, and ultimate morpho-phytotoxicity. It is concluded that $\mathrm{Cr}$-reduces plant growth and development via its excess accumulation in the plant different parts and/or disruption of nutrient uptake.
\end{abstract}

Keywords: chromium; plant; biomass; growth retardation; nutrients uptake

\section{Introduction}

Chromium $(\mathrm{Cr})$ is considered one of the major carcinogens, and is categorized 7th among the top 20 hazardous pollutants by the Environmental Protection Agency, United States of America (EPA, US) [1-3]. $\mathrm{Cr}(\mathrm{VI})$ and $\mathrm{Cr}(\mathrm{III})$ are the most stable form of $\mathrm{Cr}$ in the environment. On the bases of bioavailability in soil and translocation to different plant parts, $\mathrm{Cr}(\mathrm{VI})$ is reported to be more toxic than $\mathrm{Cr}$ (III) [3-5]. The industrial process coupled with anthropogenic and natural processes have resulted in increased accumulation of $\mathrm{Cr}$ in both terrestrial and aquatic ecosystems $[3,4,6]$. Chromium in soil and water directly affects human, animal, and plant physiology, and may accumulate within food chains, which can be a serious health threat to the secondary (herbivores) and tertiary (carnivores and omnivores) consumers $[3,7,8]$.

Various physiological factors including plant species, rate and types of root secretion, the surface area of the root, and transpiration rate regulate the absorption, translocation, and accumulation of the $\mathrm{Cr}$ in plants $[9,10]$. Chromium mainly accumulates in the plant roots that triggers the uptake and translocation of $\mathrm{Cr}$ to the aerial plant parts [11-13]. The toxic $\mathrm{Cr}$ level can provoke various morphological, physiological, biochemical, and molecular alterations in plants [14,15].

The toxic level of $\mathrm{Cr}$ inhibits plant growth and development, induces ultrastructural changes in subcellular compartments (cell wall, cell membrane, plastids, chloroplast, mitochondria, Golgi bodies, endoplasmic reticulum, vacuole, nuclei, and microtubules), persuades leaves chlorosis, root cell damage, reduces total pigment contents, disturbs water and mineral nutrition balance, alters enzymatic activities, and modulates cell division and cell cycle [3,16-20].

The process of increasing $\mathrm{Cr}$ accumulation in soil, its uptake/translocation in plants, $\mathrm{Cr}$-induced morpho-physiological, biochemical, molecular, ultrastructural, and hormonal changes in plants are 
summarized and visualized in (Figure 1). In the current study, we reviewed the most recent studies regarding $\mathrm{Cr}$-induced inhibition in seed germination and growth retardation in roots, branches, leaves, and total biomass in various plant species.

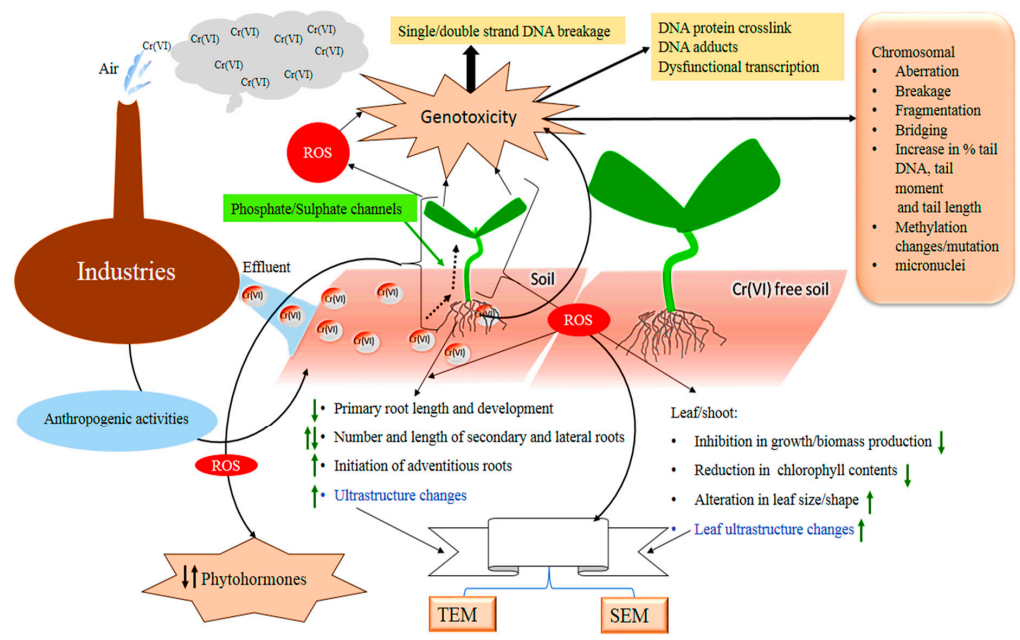

Figure 1. A functional model for the release, accumulation, and toxicity in plants. Cr is released from/through the industrial processes and anthropogenic activities in the soil. The model also visualizes the uptake of $\mathrm{Cr}$ by the plant roots, translocation to the shoots. The Cr-induced morphological, physiological, biochemical, molecular, hormonal, and ultrastructural changes in plants are also summarized in the model.

\section{Chromium-Mediated Control of Seed Germination}

The first phenotypic and physiological change mediated by $\mathrm{Cr}$ in plants is seed germination, which is very important for the continuity of the plant life cycle [21]. Endogenous and exogenous stimuli mediated genetic and epigenetic changes were reported to be involved in the regulation of seed germination, and plant biochemical, molecular and ultrastructural changes [21-23]. Chromium-induced inhibition of seed germination in various plant species have been reported, and the germination rate depends on $\mathrm{Cr}(\mathrm{VI})$ concentration and type of plant species as shown in (Table 1). Chromium stress affects the activities of both alpha and beta-amylase, which are the sources of energy provided to the emerging embryos. In summary, $\mathrm{Cr}$ reduces the activity of amylase, leading to the reduced sugar availability for energy production, and inhibits the rate of plant seed germination [24].

Table 1. Chromium-induced seed germination inhibition in various plant species.

\begin{tabular}{|c|c|c|c|c|c|c|}
\hline Plant Species & Common Name & $\begin{array}{l}\text { Chromium } \\
\text { Concentration }\end{array}$ & Medium & Time of Exposure (Days) & Seed Germination (\%) & References \\
\hline Avena sativa & Oat & $\begin{array}{c}500 \mathrm{mg} / \mathrm{kg} \mathrm{Cr}(\mathrm{VI}) \\
2000 \mathrm{mg} / \mathrm{kg} \mathrm{Cr}(\mathrm{III})\end{array}$ & Soil & 7 & $\begin{array}{l}\approx 82 \\
\approx 95\end{array}$ & [25] \\
\hline Beta vulgaris & Swiss chard & $50 \mu \mathrm{M} \mathrm{Cr}(\mathrm{III})$ & Distilled water & 12 & 71 & [26] \\
\hline Brassica juncea & Mustard & $300 \mu \mathrm{M} \mathrm{Cr}(\mathrm{VI})$ & $\begin{array}{l}\text { 1/2-strength } \\
\text { Hoagland }\end{array}$ & 3 & 80.8 & [27] \\
\hline Brassica oleracea & Cabbage & 300 mg/kg Cr(VI) & Distilled water & 3 & $\approx 65$ & [28] \\
\hline Cajanus cajan & Pigeon Pea & $100 \mathrm{ppm}$ & Distilled water & 3 & 93 & [29] \\
\hline Cucumis sativus & Cucumber & $300 \mathrm{mg} / \mathrm{kg} \mathrm{Cr}(\mathrm{VI})$ & Distilled water & 3 & $\approx 96$ & [28] \\
\hline Glycine max & Soybean & 200 mg/L Cr(VI) & Hydroponic & - & 72.6 & [30] \\
\hline Lactuca sativa & Lettuce & 300 mg/kg Cr(VI) & Distilled water & 3 & $\approx 50$ & [28] \\
\hline Lactuca sativa & Lettuce & $50 \mu \mathrm{M} \mathrm{Cr}(\mathrm{III})$ & Distilled water & 12 & 94 & [26] \\
\hline Oryza sativa & Rice & $100 \mu \mathrm{M} \mathrm{Cr}(\mathrm{VI})$ & Distilled water & 4 & $\approx 50$ & [31] \\
\hline Sorghum bicolor & Sorghum & $\begin{array}{c}500 \text { mg/kg Cr(VI) } \\
2000 \text { mg/kg Cr(III) }\end{array}$ & Soil & 7 & $\begin{array}{l}\approx 60 \\
\approx 10\end{array}$ & [25] \\
\hline Spinacia oleracea & Spinach & $50 \mu \mathrm{M} \mathrm{Cr}(\mathrm{III})$ & Distilled water & 15 & 64 & [26] \\
\hline $\begin{array}{l}\text { Triticum } \\
\text { aestivum }\end{array}$ & Wheat & $\begin{array}{c}100 \mathrm{ppm} \\
300 \mathrm{mg} / \mathrm{kg} \mathrm{Cr}(\mathrm{VI}) \\
500 \mathrm{mg} / \mathrm{kg} \mathrm{Cr}(\mathrm{VI}) \\
2000 \mathrm{mg} / \mathrm{kg} \mathrm{Cr}(\mathrm{III})\end{array}$ & $\begin{array}{l}\text { Distilled water } \\
\text { Distilled water } \\
\text { Soil }\end{array}$ & $\begin{array}{l}0.17 \\
3 \\
7\end{array}$ & $\begin{array}{l}63 \\
\approx 90 \\
\approx 70 \\
\approx 25\end{array}$ & $\begin{array}{l}{[32]} \\
{[28]} \\
{[25]}\end{array}$ \\
\hline Zea mays & Corn & $300 \mathrm{mg} / \mathrm{kg} \mathrm{Cr}(\mathrm{VI})$ & Distilled water & 3 & $\approx 99$ & [28] \\
\hline
\end{tabular}




\section{Chromium-Induced Modulation of the Root Growth and Development}

The plant root is the first organ that encounters soil pollutants, $\mathrm{Cr}$ is one of the most important soil pollutants, which affects root growth and development [14,23]. Chromium-induced reduction in the root growth mainly depends on the plant species, Cr-type and its concentration as shown in the (Table 2) Chromium is also involved in the regulations of secondary root growth and number, lateral root development, root hair, and formation of adventitious roots $[20,24,33]$. The reduced root length with a brownish appearance and reduced root hair number have been observed in Zea mays, exposed to high $\mathrm{Cr}(\mathrm{VI})$ levels [33]. The root growth inhibition mediated by $\mathrm{Cr}(\mathrm{VI})$, maybe due to the inhibition of cell division and reduction in the cell size of the elongation zone [14]. The reductions of mitotic cell division in Amaranthus viridis and Arabidopsis thaliana, have been reported, which is associated with the reduction in cell cycle-related genes and alterations in the cellular ultrastructure $[3,14]$.

Table 2. Chromium-induced reduction in root growth as compared to control of various plant species.

\begin{tabular}{|c|c|c|c|c|c|c|}
\hline Plant Species & Common Name & $\begin{array}{c}\text { Chromium } \\
\text { Concentration }\end{array}$ & Medium & $\begin{array}{l}\text { Time of Exposure } \\
\text { (Days) }\end{array}$ & $\begin{array}{c}\text { Root Growth } \\
(\%)\end{array}$ & References \\
\hline $\begin{array}{c}\text { Arabidopsis } \\
\text { thaliana }\end{array}$ & Arabidopsis & $200 \mu \mathrm{M}$ Cr(VI) & $1 / 2 \mathrm{MS}$ & 1 & 92.8 & [14] \\
\hline Avena sativa & Oat & $\begin{array}{c}500 \text { mg/kg Cr(VI) } \\
2000 \text { mg/kg Cr(III) }\end{array}$ & Soil & 7 & $\begin{array}{l}\approx 40 \\
\approx 55\end{array}$ & [25] \\
\hline Brassica campestris & Cabbage & $1 \mathrm{mg} / \mathrm{L} \mathrm{Cr}(\mathrm{VI})$ & 1/2-strength Hoagland & 21 & $\approx 35 \mathrm{FW}$ & [34] \\
\hline Brassica napus & Oilseed Rape & $400 \mu \mathrm{M} \mathrm{Cr}(\mathrm{VI})$ & Hoagland's & 6 & $\approx 50$ & [35] \\
\hline Brassica oleracea & Cabbage & 300 mg/kg Cr(VI) & Distilled water & 3 & $\approx 25$ & [28] \\
\hline Cajanus cajan & Pigeon Pea & $100 \mathrm{ppm}$ & Distilled water & 10 & 32 & [29] \\
\hline Cucumis sativus & Cucumber & 300 mg/kg Cr(VI) & Distilled water & 3 & $\approx 15$ & [28] \\
\hline Lactuca sativa & Lettuce & 300 mg/kg Cr(VI) & Distilled water & 3 & $<10$ & [28] \\
\hline Triticum aestivum & Wheat & $\begin{array}{c}500 \mu \mathrm{M} \mathrm{Cr}(\mathrm{VI}) \\
10 \mathrm{mg} / \mathrm{kg} \mathrm{Cr}(\mathrm{VI}) \\
300 \mathrm{mg} / \mathrm{kg} \mathrm{Cr}(\mathrm{VI}) \\
500 \mathrm{mg} / \mathrm{kg} \mathrm{Cr}(\mathrm{VI}) \\
2000 \mathrm{mg} / \mathrm{kg} \mathrm{Cr}(\mathrm{III})\end{array}$ & $\begin{array}{c}\text { Sand } \\
\text { Quartz sand } \\
\text { Distilled water } \\
\text { Soil }\end{array}$ & $\begin{array}{l}- \\
7 \\
3 \\
7\end{array}$ & $\begin{array}{l}\approx 57 \\
\approx 20 \\
<10 \\
\approx 10 \\
\approx 45\end{array}$ & $\begin{array}{l}{[37]} \\
{[38]} \\
{[28]} \\
{[25]}\end{array}$ \\
\hline Zea mays & Corn & $\begin{array}{c}300 \text { mg/kg Cr(VI) } \\
173 \mu \mathrm{M} \mathrm{Cr}(\mathrm{VI})\end{array}$ & $\begin{array}{l}\text { Distilled water } \\
\text { Hydroponic }\end{array}$ & $\begin{array}{l}3 \\
7\end{array}$ & $\begin{array}{l}\approx 43 \% \\
\approx 70 \%\end{array}$ & $\begin{array}{l}{[28]} \\
{[33]}\end{array}$ \\
\hline
\end{tabular}

\section{Chromium-Induced Alteration in the Shoot Growth and Development}

The growth and development of the plants' shoots are greatly compromised by the exposure to high $\mathrm{Cr}$-concentrations and the degree of toxicity depends on the plant species, $\mathrm{Cr}$-type, and concentration [3,4]. The $\mathrm{Cr}$-induced alterations in various plant species are shown in the (Table 3). In a recent study, 32 plant species were exposed to $1000 \mathrm{mg} / \mathrm{kg} \mathrm{Cr}(\mathrm{VI})$, they found that $\mathrm{Cr}(\mathrm{VI})$-reduced the stem growth of $94 \%$ species [39]. Chromium-induced stem growth inhibition maybe due to the $\mathrm{Cr}$-induced damages in the roots, which make it incapable of sufficient nutrients and water uptake [3,4]. Furthermore, the transport and accumulation of toxic Cr-level may have a direct inhibitory as well as structural and ultrastructural damaging effects on the shoot growth, development, and the capability of performing certain physiological, biochemical, molecular, and metabolic activities [3]. 
Table 3. Chromium-reduced shoot growth as compared to control in various plant species.

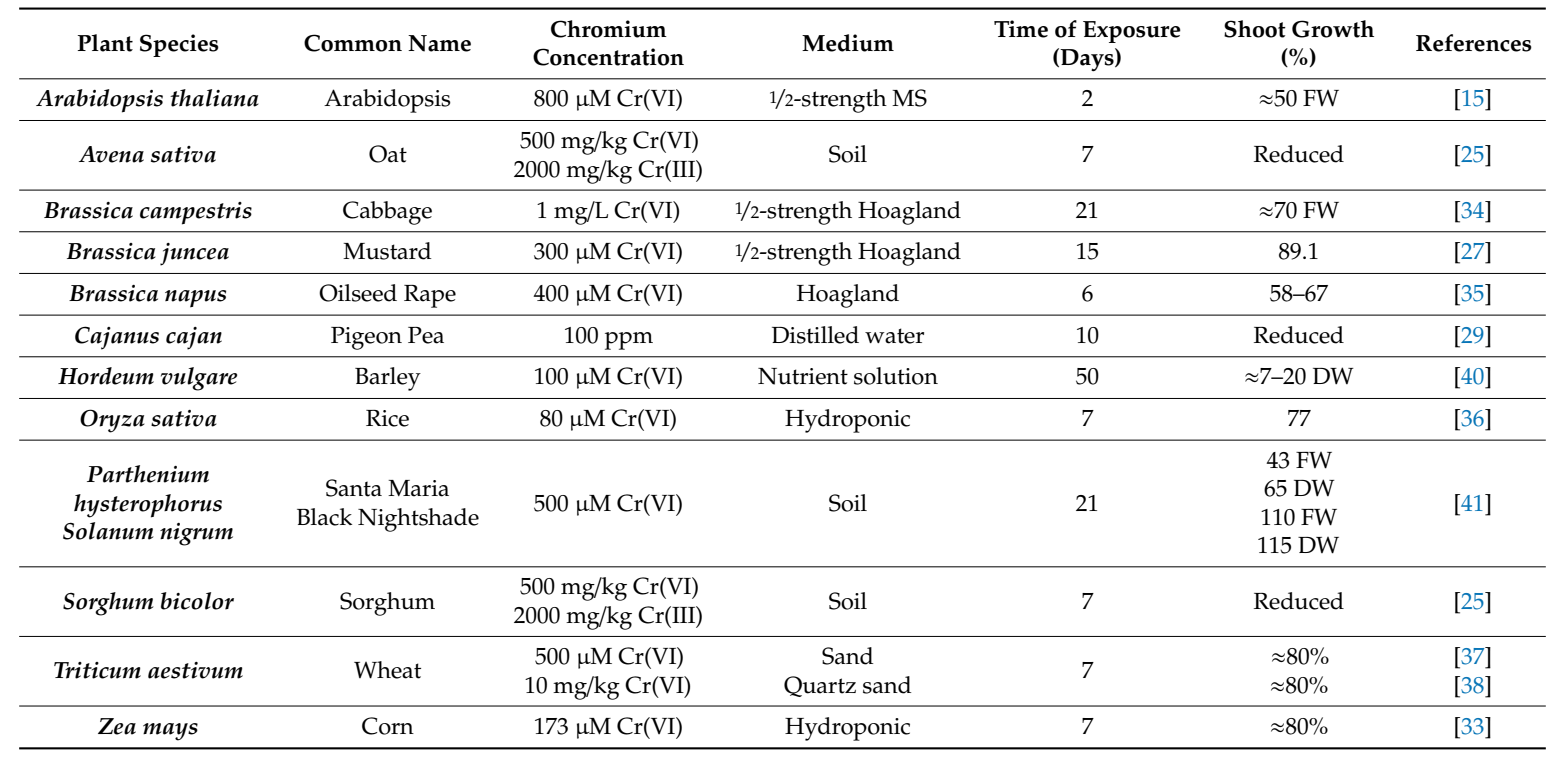

\section{Chromium Mediated Changes in Leaf Growth and Morphology}

Leaf structure and growth have been intensely investigated as an important indicator under various abiotic stresses [42]. Chromium-induced various biochemical, ultrastructural, and physiological changes have also been reported [19]. The leaf morphological changes in Cr-treated seedlings indicated that the appearance of the leaf was significantly changed in the size, and it was chlorotic and wilted as compared to those plants exposed to control condition [39,43]. The prolonged $\mathrm{Cr}$ exposure caused permanent necrosis, turned wilted and dry, and finally shed of leaves has been reported in the Cr-treated plants [44]. The reduction in leaf size of Arabidopsis thaliana upon $\mathrm{Cr}$ exposure is also reported, which can be due to the inhibition in cell division [15]. The watermelon plants exposed to $\mathrm{Cr}$ toxicity showed a phenotype of reduced number and size of leaves with a yellow appearance, wilted and turgor loss due to low water contents in the leaves [45]. Chromium-induced phenotypic alteration and growth inhibition in the leaf of various plant species have been summarized in the current review as shown in (Table 4).

Table 4. Chromium-altered leaf morphology and growth as compared to control in various plant species.

\begin{tabular}{|c|c|c|c|c|c|c|}
\hline Plant Species & Common Name & $\begin{array}{l}\text { Chromium } \\
\text { Concentration }\end{array}$ & Medium & $\begin{array}{l}\text { Time of Exposure } \\
\text { (Days) }\end{array}$ & $\begin{array}{l}\text { Induced Changes in Leaf } \\
\text { Growth and Morphology }\end{array}$ & References \\
\hline $\begin{array}{l}\text { Arabidopsis } \\
\text { thaliana }\end{array}$ & Arabidopsis & $800 \mu \mathrm{M} \mathrm{Cr}(\mathrm{VI})$ & 1/2-strength MS & 2 & $\begin{array}{l}\text { Reduced: growth, water } \\
\text { content (RWC), } \\
\text { chlorophyll (chl), cell and } \\
\text { tissue viability }\end{array}$ & [15] \\
\hline Brassica juncea & Mustard & $300 \mu \mathrm{M} \mathrm{Cr}(\mathrm{VI})$ & $\begin{array}{l}\text { Semi-hydroponic } \\
\text { medium }\end{array}$ & 5 & $\begin{array}{l}\text { Reduced: growth, RWC, } \\
\text { and chl content }\end{array}$ & [46] \\
\hline Hordeum vulgare & Barley & $100 \mu \mathrm{M} \mathrm{Cr}(\mathrm{VI})$ & Nutrient solution & 50 & $\approx 62-67 \%$ Reduced DW & [40] \\
\hline Oryza sativa & Rice & $80 \mu \mathrm{M} \mathrm{Cr}(\mathrm{VI})$ & Hydroponic & 7 & Chlorosis & [36] \\
\hline Zea mays & Corn & $173 \mu \mathrm{M} \mathrm{Cr}(\mathrm{VI})$ & Hydroponic & 7 & Reduced leaf number & [33] \\
\hline
\end{tabular}

\section{Chromium-Mediated Changes in Total Biomass Production in Plants}

The biomass production is considered proportional to yield, which is greatly compromised in the plants exposed to $\mathrm{Cr}$, indicating that $\mathrm{Cr}$ is reducing plant biomass as well as the yield of the important crops worldwide $[15,19,47,48]$. Numerous, species were investigated and reported to exhibit reduced biomass production under high $\mathrm{Cr}(\mathrm{VI})$ levels, and the toxicity varies based on the different plant species, and concentration and type of $\mathrm{Cr}(\mathrm{VI})$ used as shown in (Table 5). Several factors such as 
reduction/imbalance in the uptake/translocation of water and nutrients, cell division and division rate inhibition, selective inorganic nutrient uptake inefficiency, increased ROS accumulation, essential nutrient substitution from ligand and plant key molecules, and Cr-induced ROS mediated alteration and damages to plastids, pigment contents, mitochondria, lipids, RNA, and DNA are involved in the Cr-decreased growth, development, and yield in plants at molecular, cellular, tissue, and organ levels are involved in the alteration in the plant biomass production $[3,15-17,19,47,49,50]$. The degree of severity of these factors depends on the type of $\mathrm{Cr}$ and plant species [3]. The hyper heavy metal accumulator plants such as Brassica juncea and Alyssum maritime are were reported to be potentially more tolerant and can survive a range of high $\mathrm{Cr}$ concentrations [4,9].

Table 5. Chromium-meditated reduction in the total plant biomass as compared to control in various plant species.

\begin{tabular}{|c|c|c|c|c|c|c|}
\hline Plant Species & Common Name & $\begin{array}{l}\text { Chromium } \\
\text { Concentration }\end{array}$ & Medium & $\begin{array}{l}\text { Time of Exposure } \\
\text { (Days) }\end{array}$ & $\begin{array}{l}\text { Total Biomass } \\
\text { Production (\%) }\end{array}$ & References \\
\hline $\begin{array}{l}\text { Amaranthus viridis and } \\
\text { Amaranthus cruentus }\end{array}$ & $\begin{array}{l}\text { Green and Blood } \\
\text { Amaranth }\end{array}$ & $50 \mu \mathrm{M}$ & 1/2-strength Hoagland & 7 & $\begin{array}{l}>50 \mathrm{FW} \\
\approx 80 \mathrm{FW}\end{array}$ & [51] \\
\hline Arabidopsis thaliana & Arabidopsis & $800 \mu \mathrm{M} \mathrm{Cr}(\mathrm{VI})$ & 1/2-strength MS & 2 & $\begin{array}{l}50 \mathrm{FW} \\
75 \mathrm{DW}\end{array}$ & [15] \\
\hline Brassica juncea & Mustard & $300 \mu \mathrm{M} \mathrm{Cr}(\mathrm{VI})$ & Semi-hydroponic medium & 5 & $80-89$ growth & [46] \\
\hline Brassica juncea & Mustard & $100 \mu \mathrm{M} \mathrm{Cr}(\mathrm{VI})$ & Soil & 20 & $>50 \mathrm{FW}$ and $\mathrm{DW}$ & [52] \\
\hline Brassica napus & Oilseed Rape & $400 \mu \mathrm{M} \mathrm{Cr}(\mathrm{VI})$ & Hoagland & 6 & $67 \mathrm{DW}$ & [35] \\
\hline Brassica napus & Rapeseed & $500 \mu \mathrm{M} \mathrm{Cr}$ & Soil & 56 & $\begin{array}{l}30.6 \mathrm{FW} \\
28 \mathrm{DW}\end{array}$ & [53] \\
\hline Citrus reticulata & Kinnow Mandarin & $750 \mu \mathrm{M} \mathrm{Cr}(\mathrm{VI})$ & Soil & 120 & $63 \mathrm{DW}$ & [54] \\
\hline $\begin{array}{l}\text { Cyperus alternifolius and } \\
\text { Coix lacryma-jobi }\end{array}$ & $\begin{array}{c}\text { Umbrella Palm } \\
\text { and Adlay Millet }\end{array}$ & 40 mg/L Cr(VI) & Soil & 120 & $\begin{array}{l}77 \mathrm{DW} \\
44 \mathrm{DW}\end{array}$ & [55] \\
\hline Hordeum vulgare & Barley & $100 \mu \mathrm{M} \mathrm{Cr}(\mathrm{VI})$ & Quartz sand & 60 & $\approx 23.7 \mathrm{DW}$ & [56] \\
\hline Lemna minor & Duckweed & $500 \mu \mathrm{M} \mathrm{Cr}(\mathrm{VI})$ & SIS growth medium & 7 & 60 & [57] \\
\hline Oryza sativa & Rice & $80 \mu \mathrm{M} \mathrm{Cr}(\mathrm{VI})$ & Hydroponic & 7 & 58 & [36] \\
\hline $\begin{array}{l}\text { Parthenium hysterophorus } \\
\text { Solanum nigrum }\end{array}$ & $\begin{array}{c}\text { Santa Maria } \\
\text { Black Nightshade }\end{array}$ & $500 \mu \mathrm{M} \mathrm{Cr}(\mathrm{VI})$ & Soil & 21 & $\begin{array}{c}65.5 \mathrm{FW} \\
64 . \mathrm{DW} \\
110 \mathrm{FW} \\
106 \mathrm{DW}\end{array}$ & [41] \\
\hline Solanum melongena & Eggplant & $25 \mu \mathrm{M} \mathrm{Cr}(\mathrm{VI})$ & 1/2-strength Hoagland & 7 & $\begin{array}{l}87 \mathrm{FW} \\
83 \mathrm{DW}\end{array}$ & [48] \\
\hline Triticum aestivum & Wheat & $500 \mu \mathrm{M}$ Cr(VI) & $\begin{array}{c}\text { Sand } \\
\text { Quartz sand }\end{array}$ & 7 & $\approx 65 \%$ & [37] \\
\hline Zea mays & Corn & $173 \mu \mathrm{M} \mathrm{Cr}(\mathrm{VI})$ & Hydroponic & 7 & $\approx 85 \mathrm{FW}$ & [33] \\
\hline
\end{tabular}

\section{Chromium Interferes with the Uptake and Translocation of Macro and Micronutrients}

Chromium interferes with the nutrients uptake and translocation mechanisms of plants due to the structural similarity with the various essential ions $[58,59]$. The interference of $\mathrm{Cr}$ with the uptake and translocation of macro and micronutrients depends on the type of plant species and Cr-type. The decrease in the common nutrient uptake/translocation could be because of the competitive binding potential of $\mathrm{Cr}$ with carrier channels and reduced plasma membrane $\mathrm{H}^{+}$ATPase activity [3]. Chromium exposure may displace the nutrients from the binding sites both in the soil and inside the plant body. Mostly, $\mathrm{Cr}$ is reported for playing an antagonistic role in the uptake and translocation of essential nutrients, it also interacts synergistically with some essential nutrients such as $\mathrm{Cu}, \mathrm{Ca}, \mathrm{Mg}$, and $\mathrm{Mn}[60,61]$. The Cr-induced interruptions and variations in the nutrients uptake and translocation have been reviewed in (Table 6). 
Table 6. Chromium-induced alteration in the uptake and translocation of the essential nutrients in various plant species.

\begin{tabular}{|c|c|c|c|c|}
\hline Plant Species & Common Name & Nutrients & $\begin{array}{c}\text { Alteration in } \\
\text { Uptake/Translocation }\end{array}$ & Reference \\
\hline Cocos mucifera & Coconut Palm & $\mathrm{Fe}, \mathrm{K}, \mathrm{Cu}, \mathrm{Zn}, \mathrm{Mn}$, and $\mathrm{Mg}$ & Uptake & [3] \\
\hline Hordeum vulgare & Barley & $\mathrm{P}, \mathrm{K}, \mathrm{Mg}, \mathrm{S}, \mathrm{Fe}, \mathrm{Zn}, \mathrm{Mn}$, and $\mathrm{Ca}$ & Uptake and Translocation & [40] \\
\hline Oryza sativa & Rice & $\mathrm{N}, \mathrm{P}, \mathrm{K}, \mathrm{Ca}, \mathrm{Mg}, \mathrm{Mn}, \mathrm{Zn}, \mathrm{Fe}$, and $\mathrm{Cu}$ & Uptake/translocation & {$[63,64]$} \\
\hline Pisum sativum & Pea & Decreased micro and macronutrients (except $S$ ) & Uptake/translocation & [65] \\
\hline Raphanus sativus & Radish & $\mathrm{Fe}, \mathrm{S}, \mathrm{P}, \mathrm{Zn}, \mathrm{Mn}, \mathrm{Cu}$, and $\mathrm{B}$ & Translocation & [59] \\
\hline Solanum lycopersicum and Solanum melongena & Tomato and Eggplant & Affected N, P and K content & Translocation & [66] \\
\hline
\end{tabular}

\section{Conclusions}

Based on the available literature reviewed in the current study, we can conclude that increasing $\mathrm{Cr}$ concentration reduces plant biomass accumulation. The plants have no specialized intake channels for the $\mathrm{Cr}$ uptake. $\mathrm{Cr}$ competes with essential elements (macro and micro) for access to plant uptake machinery. High $\mathrm{Cr}$ concentration reduces the uptake of essential elements and increases its accumulation in the plant in different parts, which causes various phenotypic, ultrastructural, and biochemical changes in plants. Cr-induces endogenous plant stress molecules that may cause a reduction in plant growth and biomass accumulation. The reduction in the essential element may also participate in the retardation of plant growth and biomass production (Figure 2).

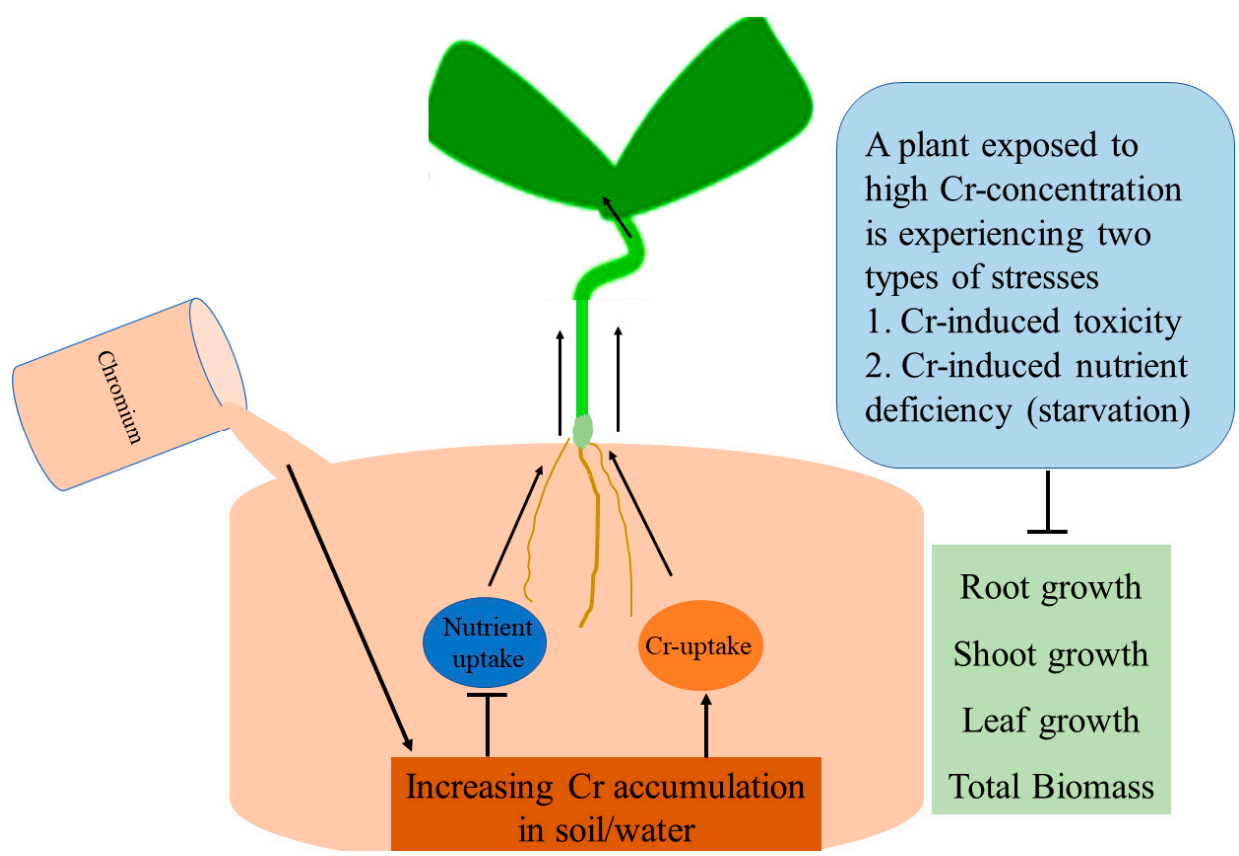

Figure 2. Functional model for the $\mathrm{Cr}$-induced nutrient uptake inhibition and plant growth retardation. Increasing concentration of $\mathrm{Cr}$ in soil/water compete with the nutrients uptake that is leading in the increasing $\mathrm{Cr}$ accumulation in plant and reduction of nutrients. So, in the presence of high $\mathrm{Cr}$ concentration plant faces two stress simultaneously: 1 . High $\mathrm{Cr}$ accumulation-mediated phytotoxicity. 2. Nutrient deficiency-mediated metabolic abnormality.

Author Contributions: Conceptualization, A.W. and M.X.; methodology, A.W; software, A.W; validation, A.W. and M.X.; formal analysis, A.W.; investigation, A.W.; resources, A.W.; data curation, A.W.; writing-original draft preparation, A.W.; writing - review and editing, A.W.; visualization, A.W.; supervision, A.W.; project administration, A.W.; funding acquisition, M.X. All authors have read and agreed to the published version of the manuscript.

Funding: This research was funded by National Key Research and Development Program of China, grant number 2018YFA0606500, 2017YFA0604300" and “The APC was funded by 2018YFA0606500, 2017YFA0604300". 
Acknowledgments: We are thankful to the National Key Research and Development Program of China (2018YFA0606500, 2017YFA0604300), for supporting this study.

Conflicts of Interest: The authors declare no conflict of interest.

\section{References}

1. Oh, Y.J.; Song, H.; Shin, W.S.; Choi, S.J.; Kim, Y.-H. Effect of amorphous silica and silica sand on removal of chromium(VI) by zero-valent iron. Chemosphere 2007, 66, 858-865. [CrossRef] [PubMed]

2. Guo, J.; Li, Y.; Dai, R.; Lan, Y. Rapid reduction of $\mathrm{Cr}(\mathrm{VI})$ coupling with efficient removal of total chromium in the coexistence of $\mathrm{Zn}(0)$ and silica gel. J. Hazard. Mater. 2012, 243, 265-271. [CrossRef] [PubMed]

3. Shahid, M.; Shamshad, S.; Rafiq, M.; Khalid, S.; Bibi, I.; Niazi, N.K.; Dumat, C.; Rashid, M.I. Chromium speciation, bioavailability, uptake, toxicity and detoxification in soil-plant system: A review. Chemosphere 2017, 178, 513-533. [CrossRef] [PubMed]

4. Ashraf, A.; Bibi, I.; Niazi, N.K.; Ok, Y.S.; Murtaza, G.; Shahid, M.; Kunhikrishnan, A.; Li, D.; Mahmood, T. Chromium(VI) sorption efficiency of acid-activated banana peel over organo-montmorillonite in aqueous solutions. Int. J. Phytoremediat. 2017, 19, 605-613. [CrossRef] [PubMed]

5. Choppala, G.; Kunhikrishnan, A.; Seshadri, B.; Park, J.H.; Bush, R.; Bolan, N. Comparative sorption of chromium species as influenced by $\mathrm{pH}$, surface charge and organic matter content in contaminated soils. J. Geochem. Explor. 2018, 184, 255-260. [CrossRef]

6. Pinter, I.F.; Salomon, M.V.; Gil, R.; Mastrantonio, L.; Bottini, R.; Piccoli, P. Arsenic and trace elements in soil, water, grapevine and onion in Jachal, Argentina. Sci. Total Environ. 2018, 615, 1485-1498. [CrossRef]

7. Huda, A.K.M.N.; Haque, M.A.; Zaman, R.; Swaraz, A.M.; Kabir, A.H. Silicon ameliorates chromium toxicity through phytochelatin-mediated vacuolar sequestration in the roots of Oryza sativa (L.). Int. J. Phytoremediat. 2017, 19, 246-253. [CrossRef]

8. Huda, A.K.M.N.; Swaraz, A.M.; Reza, M.A.; Haque, M.A.; Kabir, A.H. Remediation of Chromium Toxicity Through Exogenous Salicylic Acid in Rice (Oryza sativa L.). Water Air Soil Pollut. 2016, 227, 278. [CrossRef]

9. Ertani, A.; Mietto, A.; Borin, M.; Nardi, S. Chromium in Agricultural Soils and Crops: A Review. Water Air Soil Pollut. 2017, 228, 190. [CrossRef]

10. Herrero-Latorre, C.; Barciela-Garcia, J.; Garcia-Martin, S.; Pena-Crecente, R.M. Graphene and carbon nanotubes as solid phase extraction sorbents for the speciation of chromium: A review. Anal. Chim. Acta 2018, 1002, 1-17. [CrossRef]

11. Jaison, S.; Muthukumar, T. Chromium Accumulation in Medicinal Plants Growing Naturally on Tannery Contaminated and Non-contaminated Soils. Biol. Trace Elem. Res. 2017, 175, 223-235. [CrossRef] [PubMed]

12. Rani, P.; Kumar, A.; Arya, R.C. Stabilization of tannery sludge amended soil using Ricinus communis, Brassica juncea and Nerium oleander. J. Soils Sediments 2017, 17, 1449-1458. [CrossRef]

13. Shen, Z.J.; Xu, D.C.; Chen, Y.S.; Zhang, Z. Heavy metals translocation and accumulation from the rhizosphere soils to the edible parts of the medicinal plant Fengdan (Paeonia ostii) grown on a metal mining area, China. Ecotoxicol. Environ. Saf. 2017, 143, 19-27. [CrossRef] [PubMed]

14. Wakeel, A.; Ali, I.; Upreti, S.; Azizullah, A.; Liu, B.; Khan, A.R.; Huang, L.; Wu, M.; Gan, Y. Ethylene mediates dichromate-induced inhibition of primary root growth by altering AUX1 expression and auxin accumulation in Arabidopsis thaliana. Plant Cell Environ. 2018, 41, 1453-1467. [CrossRef]

15. Wakeel, A.; Ali, I.; Wu, M.; Kkan, A.R.; Jan, M.; Ali, A.; Liu, Y.; Ge, S.; Wu, J.; Gan, Y. Ethylene mediates dichromate-induced oxidative stress and regulation of the enzymatic antioxidant system-related transcriptome in Arabidopsis thaliana. Environ. Exp. Bot. 2019, 161, 166-179. [CrossRef]

16. Castro, R.O.; Trujillo, M.M.; Bucio, J.L.; Cervantes, C. Effects of dichromate on growth and root system architecture of Arabidopsis thaliana seedlings. Plant Sci. 2007, 173, 71. [CrossRef]

17. Lopez-Bucio, J.; Hernandez-Madrigal, F.; Cervantes, C.; Ortiz-Castro, R.; Carreon-Abud, Y.; Martinez-Trujillo, M. Phosphate relieves chromium toxicity in Arabidopsis thaliana plants by interfering with chromate uptake. Biometals 2014, 27, 363-370. [CrossRef]

18. Martinez-Trujillo, M.; Mendez-Bravo, A.; Ortiz-Castro, R.; Hernandez-Madrigal, F.; Ibarra-Laclette, E.; Ruiz-Herrera, L.F.; Long, T.A.; Cervantes, C.; Herrera-Estrella, L.; Lopez-Bucio, J. Chromate alters root system architecture and activates expression of genes involved in iron homeostasis and signaling in Arabidopsis thaliana. Plant Mol. Biol. 2014, 86, 35-50. [CrossRef] 
19. Eleftheriou, E.P.; Adamakis, I.-D.S.; Panteris, E.; Fatsiou, M. Chromium-Induced Ultrastructural Changes and Oxidative Stress in Roots of Arabidopsis thaliana. Int. J. Mol. Sci. 2015, 16, 15852-15871. [CrossRef]

20. Lopez-Bucio, J.; Ortiz-Castro, R.; Ruiz-Herrera, L.F.; Juarez, C.V.; Hernandez-Madrigal, F.; Carreon-Abud, Y.; Martinez-Trujillo, M. Chromate induces adventitious root formation via auxin signalling and SOLITARY-ROOT/IAA14 gene function in Arabidopsis thaliana. Biometals 2015, 28, 353-365. [CrossRef]

21. Xu, W.; Wang, Q.; Yang, W.; Sun, J.; Dai, T. Effect of Chromium $(\mathrm{Cr} \sim(6+))$ Stress on Seed Germination, Anti-oxidation and Osmotic Adjustment in Seedling of Different Genotypes of Wheat. J. Triticeae Crop. 2017, 37, 1112-1119.

22. Ali, I.; Wakeel, A.; Upreti, S.; Liu, D.; Azizullah, A.; Jan, M.; Ullah, W.; Liu, B.; Ali, A.; Daud, M. Effect of Bisphenol A-induced Oxidative Stress on the Ultra Structure and Antioxidant Defence System of Arabidopsis thialiana Leaves. Pol. J. Environ. Stud. 2018, 27. [CrossRef]

23. Wakeel, A.; Ali, I.; Khan, A.R.; Wu, M.; Upreti, S.; Liu, D.; Liu, B.; Gan, Y. Involvement of histone acetylation and deacetylation in regulating auxin responses and associated phenotypic changes in plants. Plant Cell Rep. 2018, 37, 51-59. [CrossRef]

24. Zeid, I.M. Responses of Phaseolus vulgaris to chromium and cobalt treatments. Biol. Plant. 2001, 44, 111-115. [CrossRef]

25. Lopez-Luna, J.; Gonzalez-Chavez, M.C.; Esparza-Garcia, F.J.; Rodriguez-Vazquez, R. Toxicity assessment of soil amended with tannery sludge, trivalent chromium and hexavalent chromium, using wheat, oat and sorghum plants. J. Hazard. Mater. 2009, 163, 829-834. [CrossRef] [PubMed]

26. Bautista, O.V.; Fischer, G.; Cárdenas, J.F. Cadmium and chromium effects on seed germination and root elongation in lettuce, spinach and Swiss chard. Agronomía Colombiana 2013, 31, 48-57.

27. Handa, N.; Kohli, S.K.; Thukral, A.K.; Bhardwaj, R.; Alyemeni, M.N.; Wijaya, L.; Ahmad, P. Protective role of selenium against chromium stress involving metabolites and essential elements in Brassica juncea L. seedlings. 3 Biotech 2018, 8, 66. [CrossRef]

28. Hou, J.; Liu, G.-N.; Xue, W.; Fu, W.-J.; Liang, B.-C.; Liu, X.-H. Seed germination, root elongation, root-tip mitosis, and micronucleus induction of five crop plants exposed to chromium in fluvo-aquic soil. Environ. Toxicol. Chem. 2014, 33, 671-676. [CrossRef]

29. Dotaniya, M.L.; Meena, V.D.; Das, H. Chromium toxicity on seed germination, root elongation and coleoptile growth of pigeon pea (Cajanus cajan). Legume Res. 2014, 37, 227-229. [CrossRef]

30. Xu, F.; Deng, J. Effects of Salicylic Acid on Germination of Soybean Seed under Chromium Stress. Soybean Sci. 2012, 31, 852-854.

31. Shinwari, K.I.; Jan, M.; Shah, G.; Khattak, S.R.; Urehman, S.; Daud, M.K.; Naeem, R.; Jamil, M. Seed priming with salicylic acid induces tolerance against chromium (VI) toxicity in rice (Oryza sativa L.). Pak. J. Bot. 2015, 47, 161-170.

32. Dotaniya, M.L.; Das, H.; Meena, V.D. Assessment of chromium efficacy on germination, root elongation, and coleoptile growth of wheat (Triticum aestivum L.) at different growth periods. Environ. Monit. Assess. 2014, 186, 2957-2963. [CrossRef] [PubMed]

33. Mallick, S.; Sinam, G.; Mishra, R.K.; Sinha, S. Interactive effects of Cr and Fe treatments on plants growth, nutrition and oxidative status in Zea mays L. Ecotoxicol. Environ. Saf. 2010, 73, 987-995. [CrossRef] [PubMed]

34. Qing, X.; Zhao, X.; Hu, C.; Wang, P.; Zhang, Y.; Zhang, X.; Wang, P.; Shi, H.; Jia, F.; Qu, C. Selenium alleviates chromium toxicity by preventing oxidative stress in cabbage (Brassica campestris L. ssp Pekinensis) leaves. Ecotoxicol. Environ. Saf. 2015, 114, 179-189. [CrossRef] [PubMed]

35. Gill, R.A.; Zhang, N.; Ali, B.; Farooq, M.A.; Xu, J.; Gill, M.B.; Mao, B.; Zhou, W. Role of exogenous salicylic acid in regulating physio-morphic and molecular changes under chromium toxicity in black- and yellowseeded Brassica napus L. Environ. Sci. Pollut. Res. 2016, 23, 20483-20496. [CrossRef]

36. Chen, Q.; Zhang, X.; Liu, Y.; Wei, J.; Shen, W.; Shen, Z.; Cui, J. Hemin-mediated alleviation of zinc, lead and chromium toxicity is associated with elevated photosynthesis, antioxidative capacity; suppressed metal uptake and oxidative stress in rice seedlings. Plant Growth Regul. 2017, 81, 253-264. [CrossRef]

37. Adrees, M.; Ali, S.; Iqbal, M.; Bharwana, S.A.; Siddiqi, Z.; Farid, M.; Ali, Q.; Saeed, R.; Rizwan, M. Mannitol alleviates chromium toxicity in wheat plants in relation to growth, yield, stimulation of anti-oxidative enzymes, oxidative stress and $\mathrm{Cr}$ uptake in sand and soil media. Ecotoxicol. Environ. Saf. 2015, 122, 1-8. [CrossRef] 
38. Lopez-Luna, J.; Silva-Silva, M.J.; Martinez-Vargas, S.; Mijangos-Ricardez, O.F.; Gonzalez-Chavez, M.C.; Solis-Dominguez, F.A.; Cuevas-Diaz, M.C. Magnetite nanoparticle (NP) uptake by wheat plants and its effect on cadmium and chromium toxicological behavior. Sci. Total Environ. 2016, 565, 941-950. [CrossRef]

39. Lukina, A.O.; Boutin, C.; Rowland, O.; Carpenter, D.J. Evaluating trivalent chromium toxicity on wild terrestrial and wetland plants. Chemosphere 2016, 162, 355-364. [CrossRef]

40. Ali, S.; Zeng, F.; Qiu, B.; Cai, S.; Qiu, L.; Wu, F.; Zhang, G. Interactive effects of aluminum and chromium stresses on the uptake of nutrients and the metals in barley. Soil Sci. Plant Nutr. 2011, 57, 68-79. [CrossRef]

41. UdDin, I.; Bano, A.; Masood, S. Chromium toxicity tolerance of Solanum nigrum L. and Parthenium hysterophorus L. plants with reference to ion pattern, antioxidation activity and root exudation. Ecotoxicol. Environ. Saf. 2015, 113, 271-278. [CrossRef] [PubMed]

42. Ali, I.;Jan, M.; Wakeel, A.; Azizullah, A.; Liu, B.; Islam, F.; Ali, A.; Daud, M.K.; Liu, Y.; Gan, Y. Biochemical responses and ultrastructural changes in ethylene insensitive mutants of Arabidopsis thialiana subjected to bisphenol A exposure. Ecotoxicol. Environ. Saf. 2017, 144, 62-71. [CrossRef] [PubMed]

43. Chatterjee, J.; Chatterjee, C. Phytotoxicity of cobalt, chromium and copper in cauliflower. Environ. Pollut. 2000, 109, 69-74. [CrossRef]

44. Dubey, S.; Misra, P.; Dwivedi, S.; Chatterjee, S.; Bag, S.K.; Mantri, S.; Asif, M.H.; Rai, A.; Kumar, S.; Shri, M.; et al. Transcriptomic and metabolomic shifts in rice roots in response to Cr (VI) stress. BMC Genom. 2010, 11, 648. [CrossRef]

45. Dube, B.K.; Tewari, K.; Chatterjee, J.; Chatterjee, C. Excess chromium alters uptake and translocation of certain nutrients in citrullus. Chemosphere 2003, 53, 1147-1153. [CrossRef]

46. Mahmud, J.A.L.; Hasanuzzaman, M.; Nahar, K.; Rahman, A.; Hossain, M.S.; Fujita, M. gamma-aminobutyric acid (GABA) confers chromium stress tolerance in Brassica juncea L. by modulating the antioxidant defense and glyoxalase systems. Ecotoxicology 2017, 26, 675-690. [CrossRef]

47. Shanker, A.K.; Cervantes, C.; Loza-Tavera, H.; Avudainayagam, S. Chromium toxicity in plants. Environ. Int. 2005, 31, 739-753. [CrossRef]

48. Singh, M.; Kushwaha, B.K.; Singh, S.; Kumar, V.; Singh, V.P.; Prasad, S.M. Sulphur alters chromium (VI) toxicity in Solarium melongena seedlings: Role of sulphur assimilation and sulphur-containing antioxidants. Plant Physiol. Biochem. 2017, 112, 183-192. [CrossRef]

49. Cervantes, C.; Campos-Garcia, J.; Devars, S.; Gutierrez-Corona, F.; Loza-Tavera, H.; Torres-Guzman, J.C.; Moreno-Sanchez, R. Interactions of chromium with microorganisms and plants. Fems Microbiol. Rev. 2001, 25, 335-347. [CrossRef]

50. Singh, H.P.; Mahajan, P.; Kaur, S.; Batish, D.R.; Kohli, R.K. Chromium toxicity and tolerance in plants. Environ. Chem. Lett. 2013, 11, 229-254. [CrossRef]

51. Bashri, G.; Parihar, P.; Singh, R.; Singh, S.; Singh, V.P.; Prasad, S.M. Physiological and biochemical characterization of two Amaranthus species under Cr(VI) stress differing in $\mathrm{Cr}(\mathrm{VI})$ tolerance. Plant Physiol. Biochem. 2016, 108, 12-23. [CrossRef] [PubMed]

52. Ashfaque, F.; Inam, A.; Inam, A.; Iqbal, S.; Sahay, S. Response of silicon on metal accumulation, photosynthetic inhibition and oxidative stress in chromium-induced mustard (Brassica juncea L.). S. Afr. J. Bot. 2017, 111, 153-160. [CrossRef]

53. Afshan, S.; Ali, S.; Bharwana, S.A.; Rizwan, M.; Farid, M.; Abbas, F.; Ibrahim, M.; Mehmood, M.A.; Abbasi, G.H. Citric acid enhances the phytoextraction of chromium, plant growth, and photosynthesis by alleviating the oxidative damages in Brassica napus L. Environ. Sci. Pollut. Res. 2015, 22, 11679-11689. [CrossRef] [PubMed]

54. Balal, R.M.; Shahid, M.A.; Vincent, C.; Zotarelli, L.; Liu, G.; Mattson, N.S.; Rathinasabapathi, B.; Martinez-Nicolas, J.J.; Garcia-Sanchez, F. Kinnow mandarin plants grafted on tetraploid rootstocks are more tolerant to Cr-toxicity than those grafted on its diploids one. Environ. Exp. Bot. 2017, 140, 8-18. [CrossRef]

55. Li, S.; Huang, H.; Li, Z.; Li, Z.; He, Z.; Liang, H. Chromium removal capability and photosynthetic characteristics of Cyperus alternifolius and Coix lacryma-jobi L. in vertical flow constructed wetland treated with hexavalent chromium bearing domestic sewage. Water Sci. Technol. 2017, 76, 2203-2212. [CrossRef]

56. Ali, S.; Farooq, M.A.; Yasmeen, T.; Hussain, S.; Arif, M.S.; Abbas, F.; Bharwana, S.A.; Zhang, G. The influence of silicon on barley growth, photosynthesis and ultra-structure under chromium stress. Ecotoxicol. Environ. Saf. 2013, 89, 66-72. [CrossRef] 
57. Reale, L.; Ferranti, F.; Mantilacci, S.; Corboli, M.; Aversa, S.; Landucci, F.; Baldisserotto, C.; Ferroni, L.; Pancaldi, S.; Venanzoni, R. Cyto-histological and morpho-physiological responses of common duckweed (Lemna minor L.) to chromium. Chemosphere 2016, 145, 98-105. [CrossRef]

58. Tiwari, K.K.; Dwivedi, S.; Singh, N.K.; Rai, U.N.; Tripathi, R.D. Chromium (VI) induced phytotoxicity and oxidative stress in pea (Pisum sativum L.): Biochemical changes and translocation of essential nutrients. J. Environ. Biol. 2009, 30, 389-394.

59. Tiwari, K.K.; Singh, N.K.; Rai, U.N. Chromium Phytotoxicity in Radish (Raphanus sativus): Effects on Metabolism and Nutrient Uptake. Bull. Environ. Contam. Toxicol. 2013, 91, 339-344. [CrossRef]

60. Dong, J.; Wu, F.; Huang, R.; Zang, G. A chromium-tolerant plant growing in Cr-contaminated land. Int. J. Phytoremediat. 2007, 9, 167-179. [CrossRef]

61. Vernay, P.; Gauthier-Moussard, C.; Hitmi, A. Interaction of bioaccumulation of heavy metal chromium with water relation, mineral nutrition and photosynthesis in developed leaves of Lolium perenne L. Chemosphere 2007, 68, 1563-1575. [CrossRef] [PubMed]

62. Dias, M.C.; Moutinho-Pereira, J.; Correia, C.; Monteiro, C.; Araujo, M.; Brueggemann, W.; Santos, C. Physiological mechanisms to cope with $\mathrm{Cr}(\mathrm{VI})$ toxicity in lettuce: Can lettuce be used in Cr phytoremediation? Environ. Sci. Pollut. Res. 2016, 23, 15627-15637. [CrossRef] [PubMed]

63. Sundaramoorthy, P.; Chidambaram, A.; Ganesh, K.S.; Unnikannan, P.; Baskaran, L. Chromium stress in paddy: (i) Nutrient status of paddy under chromium stress; (ii) Phytoremediation of chromium by aquatic and terrestrial weeds. Comptes Rendus Biol. 2010, 333, 597-607. [CrossRef] [PubMed]

64. Zeng, F.; Qiu, B.; Ali, S.; Zhang, G. Genotypic differences in nutrient uptake and accumulation in rice under chromium stress. J. Plant Nutr. 2010, 33, 518-528. [CrossRef]

65. Tripathi, D.K.; Singh, V.P.; Prasad, S.M.; Chauhan, D.K.; Dubey, N.K. Silicon nanoparticles (SiNp) alleviate chromium (VI) phytotoxicity in Pisum sativum (L.) seedlings. Plant Physiol. Biochem. 2015, 96, 189-198. [CrossRef]

66. Gautam, M.; Singh, A.K.; Johri, R.M. Effect of chromium toxicity on growth, chlorophyll and some macronutrients of Solanum lycopersicum and Solanum melongena. Indian J. Agric. Sci. 2014, 84, 1115-1123.

(C) 2020 by the authors. Licensee MDPI, Basel, Switzerland. This article is an open access article distributed under the terms and conditions of the Creative Commons Attribution (CC BY) license (http://creativecommons.org/licenses/by/4.0/). 